\title{
Detection of c-erbB-2 mRNAs using dig-labelled oligonucleotide probe with in situ hybridisation in human breast carcinoma: Comparison with immunohistochemical results
}

\author{
Melek Öztürk ${ }^{\mathrm{a}, *}$, Sema Bolkent $^{\mathrm{a}}$, Selma Yilmazer ${ }^{\mathrm{a}}$, Gültekin Kaner ${ }^{\mathrm{b}}$ and Hilal Ünal $^{\mathrm{c}}$ \\ ${ }^{a}$ Department of Medical Biology, Cerrahpaşa Faculty of Medicine, University of Istanbul, Turkey \\ ${ }^{\mathrm{b}}$ Department of Pathology, Cerrahpaşa Faculty of Medicine, University of Istanbul, Turkey \\ ${ }^{\mathrm{c}}$ Department of Surgery, Cerrahpaşa Faculty of Medicine, University of Istanbul, Turkey
}

Received 8 October 1997

Revised 23 March 1998

Accepted 14 April 1998

\begin{abstract}
Amplification and overexpression of the c-erbB-2 oncogene are of prognostic significance in human breast cancer. Overexpression of c-erbB-2 is the result of gene amplification. However, increased transcript levels of c-erbB-2 are also detected in the absence of gene amplification. In this study for the detection of the overexpression mRNA in situ hybridisation (ISH) and immunohistochemistry (IHC) were used. Our aim was to develop the suitable mRNA ISH protocol for formalin-fixed paraffin-embedded material and to compare the localisation of transcripts and protein products in 20 primary breast carcinomas. Sections were immunostained with monoclonal c-erbB-2 antibody. In ISH method digoxigenin-labelled oligoprobe was used for the detection of c-erbB-2 mRNAs. We determined optimal condition for the ISH procedure (e.g., probe concentration, digestion, post washing). c-erbB-2 protein overproduction was detected in 11/20 cases with IHC. The mRNA signals were observed in malignant cell cytoplasm in $6 / 20$ cases by ISH. ISH positive signals were found in only one case without detected overexpression of the protein. There were cell to cell variations in the hybridisation signals even within individual tumours. The ISH and IHC positive signals for c-erbB-2 was observed mostly in infiltrating ductal carcinomas that belong to aggressive lesions.
\end{abstract}

Keywords: c-erbB-2, breast cancer, in situ hybridisation, immunohistochemistry

\section{Introduction}

The c-erbB-2 oncogene (also called HER2/neu) encodes an MW 185 KD transmembrane glycoprotein [5]. It is structuraly similar to the epidermal growth factor receptor [34]. Amplification and overexpression of c-erbB-2 gene appears to play a role in the pathogenesis of human breast $[14,25,33]$ and other [23,24] cancers. Clinical interest in c-erbB-2 gene in breast cancer was initiated by Slamon et al. [28] who suggested that gene amplification and enhanced c-erbB-2 expression are associated with

\footnotetext{
*Corresponding author: Department of Medical Biology, Cerrahpaşa Faculty of Medicine, University of Istanbul, Istanbul 34300, Turkey. Tel.: + 90 (0212) 5884800, ext. 2252; Fax: +90 (0212) 6320050; E-mail: ozturkmel@ superonline.com.
} 
poor prognosis of breast cancer. The elevated expression of the c-erbB-2 gene and its involvement in neoplasia are suggestive of its important role(s) in abnormal growth and cellular transformation $[3,15]$. Immunohistochemistry [2,8,18], PCR [8,28], Southern blot [4] or DNA in situ hybridisation [11,17,27, $29,30]$ techniques have been used for determining c-erbB-2 gene amplification.

Overexpression of c-erbB-2 occurs generally as a consequence of gene amplification. However, in the recent years the comparative studies have showed that the overexpression of c-erbB-2 oncoprotein and mRNA could occur without gene amplification [1,13,17]. For this reason, mRNA ISH is one of the suitable methods for the detection of overexpression which occurs a result of amplification or other mechanism. There are a few studies indicating the localisation of c-erbB-2 mRNAs in the tissue using different non-radioactive ISH methods [30]. In this study, our aim was to develop the most appropriate ISH protocol to the laboratory conditions by using digoxigenin (DIG)-labelled oligoprobe to determine mRNA transcripts of c-erbB-2 oncogene in breast carcinoma tissue sections and to compare ISH results with the immunohistochemical results.

We applied the ISH technique to the newly prepared formalin-fixed paraffin-embedded biopsy material and to the archival tissues because of the possibility of the retrospective studies. Previously, ISH archival studies on c-erbB-2 have been reported in mRNA ISH method which detected the stable-existing mRNAs within overlong period archival material [30] and in DNA ISH method [17] as reliable and having clinical utulity. However, the ISH method for detecting DNA amplification does not asses the overexpressed gene product in the absence of gene amplification. mRNA in situ hybridisation will allow detection of gene activation even if protein is not expressed due to disfunction of translation. On the other hand, correlation with the oncoprotein will provide knowledge of gene activation and protein synthesis within a cell type.

\section{Material and methods}

\subsection{Tissues}

Twenty primary breast carcinoma biopsy materials were selected for this study. The formalin-fixed paraffin-embedded tissue sections of $5 \mu \mathrm{m}$ thickness were stained with hematoxylin-eosin then evaluated histopatologically. The sections of all cases were assessed for type using WHO criteria, and for histological differentiation using a modification of Tavassoli FA criteria [31] (Table 2).

\subsection{Probes and labelling}

Human c-erbB-2/neu antisense and sense oligonucleotide probes (40 base synthetic oligonucleotide, $60 \%$ GC content) obtained from Oncogene Science Company (cat. no.: ON 112-ON, 112 S). Probes were labelled by the tailing technique with digoxigenin-conjugated deoxyuridine triphospate (DIG-11dUTP) according to the manufacture's recommendation (Bohringer, Mannheim). The labelling procedure is briefly as following: $4 \mu \mathrm{l}$ tailing buffer, $4 \mu \mathrm{CoCl}_{2}$ solution, 100 pmol oligonucleotide, $1 \mu \mathrm{l}$ DIG d-UTP solution, $1 \mu \mathrm{l}$ dATP solution, $1 \mu \mathrm{l} \cong 50$ units terminal transferase were mixed and made up to a final volume of $20 \mu \mathrm{l}$ with sterile redistilled water. Then incubated at $37^{\circ} \mathrm{C}$ for $15 \mathrm{~min}$ on ice. A glycogen solution of $1 \mu \mathrm{l}$ were mixed with $200 \mu \mathrm{l} 0.2 \mathrm{M}$ EDTA pH 8.0 and added $2 \mu \mathrm{l}$ to the reaction mixture to stop the reaction. The tailed oligonucleotide was precipitated with $2.5 \mu \mathrm{l} 4 \mathrm{M} \mathrm{LiCl}$ and $75 \mu \mathrm{l}$ absolute ethanol $\left(-20^{\circ} \mathrm{C}\right)$ then mixed well and left for $30 \mathrm{~min}$ at $70^{\circ} \mathrm{C}$, then centrifuged, washed the pellet with $50 \mu \mathrm{l}$ cold ethanol $70 \%(\mathrm{v} / \mathrm{v})$, dried under vacuum and dissolved in an appropriate volume of sterile redistilled water. 


\subsection{In situ hybridisation}

Tissue sections of $5 \mu \mathrm{m}$ were cut onto poly-L-lysine slides and left overnight to dry at $37^{\circ} \mathrm{C}$. Sections were deparaffinized in xylene and rehydrated through a series of ethanol down to DEPC water (for every step diethyl-pyrocarbonate-treated Mili-Q water was used). Sections were immersed in $0.2 \mathrm{M} \mathrm{HCl}$ solution for 10 min to eliminate endogenous alkaline phosphatase activity. After acid treatment the sections were washed in $0.1 \mathrm{M}$ phosphate-buffered saline (PBS), then treated with pepsin $(0.02 \%)$ at $37^{\circ} \mathrm{C} 30 \mathrm{~min}$. Thereafter, the tissue sections were postfixed in freshly prepared 4\% paraformaldehyde in PBS for 20 min at $4^{\circ} \mathrm{C}$, rinsed in PBS and then immersed in $0.25 \%$ acetic anhydride, $0.1 \mathrm{M}$ triethanolamine and $0.9 \%$ $\mathrm{NaCl}$ for $10 \mathrm{~min}$ at room temperature. Prehybridisation was carried out at $37^{\circ} \mathrm{C}$ for $1 \mathrm{~h}$ in hybridisation solution (BBS2 R\&D Systems containing $0.6 \mathrm{M}$ salt, $30 \%$ an (v/v) formamid, $150 \mathrm{mg} / \mathrm{ml}$ sonicated salmon sperm DNA). Then all slides except the no-probe controls were drained prior to the application of the probe (mixture in hybridisation-buffer) and incubated at $37^{\circ} \mathrm{C}$ in the humid chamber overnight. DIGlabelled oligonucleotide probes (antisense or sense) at a final concentration was $200 \mathrm{ng} / \mathrm{ml}$. After hybridisation, all slides were washed in fresh $1 \times \mathrm{SSC}$ (saline sodium citrate) at $55^{\circ} \mathrm{C}$ three times for $30 \mathrm{~min}$ $(3 \times 30 \mathrm{~min})$ followed by $1 \times \mathrm{SSC}$ at room temperature for $1 \mathrm{~h}$. Sections were washed in $1 \times$ modified Tris buffer $(1 \times \mathrm{TBS})$ containing $0.1 \%$ Triton-X $100(50 \mathrm{mM}$ Tris $\mathrm{pH} 7.6,150 \mathrm{mM} \mathrm{NaCl}, 2 \mathrm{mM} \mathrm{MgCl}$, $0.1 \%$ bovine serum albumin, $0.1 \%$ Triton-X) for $30 \mathrm{~min}$ at room temperature. Detection of DIG-labelled probes were carried out using the R\&D Systems Code BBS 8. Briefly, the detection reaction: sheep anti-digoxigenin alkaline phosphatase (AP) conjugated was diluted in $1 \times$ TBS $(1: 1000)$ and sections incubated overnight at $4{ }^{\circ} \mathrm{C}$, then washed in $1 \times$ TBS $(3 \times 30 \mathrm{~min})$. The sections were then incubated in coloured substrates $\left(0.125 \mathrm{M}\right.$ Tris $\mathrm{pH} 9.5,1 \mathrm{M} \mathrm{NaCl}, 0.5 \mathrm{M} \mathrm{MgCl}_{2}$, 5-bromo-4-chloro-3-indolyphosphate (BCIP) and nitroblue tetrazolium (NBT) chromogen) for $2-4 \mathrm{~h}$ at $37^{\circ} \mathrm{C}$ in the dark damp chamber. The anti-digoxigenin antibody bound AP reacts with NBT/BCIP to generate a dark purple-brown precipitation at the site of DIG-probe hybridisation. Sections were then rinsed in PBS and coverslipped by using mounting medium (gelatine and glycerol with distilled water in the ratio $1: 7: 6$, respectively).

\subsection{Immunohistochemistry}

Immunostaining for c-erbB-2 oncoprotein was carried out with CB11 monoclonal antibody (Biogenex Laboratories, San Ramon, CA) and immunoperoxidase technique. Sections were deparaffinized. Endogenous peroxidase was blocked with $0.03 \%$ hydrogen peroxide for $30 \mathrm{~min}$. Sections were incubated overnight at $+4{ }^{\circ} \mathrm{C}$ with c-erbB-2 antibody (prediluted by manufacturer). Specific reactivity was detected with biotinylated secondary antibody and the streptavidin peroxidase complex, and 3-amino-9ethyl carbozole (AEC) were used as the chromogen. Detection procedures were carried out as described by the manufacturer (high performance immunostaining kit; biotin-streptavidin-anti-peroxidase, Biogenex Laboratories, San Ramon, CA). Slides were counterstain with hematoxylin.

\subsection{Controls for specificity}

DIG-labelled poly-d(T) oligoprobe were used as a positive control probe (R\&D Systems, BBS 8). Formamide was omitted when using oligo- $\mathrm{d}(\mathrm{T})$ both prehybridisation and hybridisation solutions. DIGlabelled c-erbB-2 sense oligoprobe was used as a negative control probe. The omission of probe or RNase pre-treatment of the tissue sections before hybridisation were applied for negative controls. The specificity of antibody: no staining was observed in the negative control in the case of the omission of primer antibody. In addition, tissues were stained with non-immune serum as the first layer or with 
inappropriate antiserum (rabbit anti-insulin) as the first layer. All these gave negative results. Breast tissue slides (Biogenex, FGMULTI-5, Breast sausage FG000) were also used as a positive control tissue sections.

\section{Results}

\subsection{Detection of c-erbB-2 overexpression by non-radioactive ISH}

Several attempts were made to develop the non-radioactive ISH protocol compatible with the tissue in order to determine c-erbB-2 gene overexpression in breast cancers. We used proteinase-K (PK) in various concentrations (from 1 to $10 \mu \mathrm{g} / \mathrm{ml}$ ) and for various durations (from 10 to $60 \mathrm{~min}$ ) within ISH protocol. We obtained high background in all of these applications. However, pepsin $\left(0.02 \%, 37^{\circ} \mathrm{C}\right.$, $30 \mathrm{~min}$ ) yielded a lower background than PK. Furthermore, acid pre-treatment reduced the endogenous alkaline phosphatase activity without affecting the efficiency of hybridisation.

We tried various probe concentrations (from 50 to $200 \mathrm{ng} / \mathrm{ml}$ ). Optimum probe concentration was found to be $200 \mathrm{ng} / \mathrm{ml}$ concentration. Hybridisation signals were localised by the presence of the darkpurple-brown chromogen reaction in neoplastic cell cytoplasm (Fig. 1) in 6 of 20 cases (30\%), while normal breast tissue was negative. Non-specific background was present in some sections. There were the differences in the staining intensity between the ISH positive cases. In addition, there were considerable cell-to-cell variations in hybridisation signal within individual tumours. Cells exhibiting strong or weak hybridisation signals were generally scattered at random throughout individual tumours. Six of the cases giving positive hybridisation signals from 20 primary breast carcinoma cases were infiltrating ductal carcinoma (30\%) (Table 1$)$.

\subsection{Detection of c-erbB-2 oncoprotein by immunohistochemistry}

In this study, samples were classified as immunoreactive when a distinct cell membrane staining was observed. In some cases the cytoplasm was faintly stained. Cytoplasmic staining was not included in the immunoreactive positive group. The cellular membrane of tumoural cells in 11/20 (55\%) cases was intensely stained with monoclonal c-erbB-2 antibody (Fig. 2). Adjacent normal tissue did not show any positive signal. c-erbB-2 overproduction was detected in infiltrating ductal carcinoma $(8 / 11,73 \%)$ which has grade II (5/8) and grade III (3/8) and in situ ductal carcinoma (3/11, 27\%) (Table 1).

When compared with ISH and IHC reactivity, ISH positive signals were found in only one case without detected overexpression of the protein. Whereas in the other six c-erbB-2 oncoprotein positive cases, ISH signals were negative. The positive signals both ISH and IHC in the same case were seen in the infiltrating ductal carcinomas (Tables 1 and 2).

Table 1

Detection of c-erbB-2 mRNA and oncoprotein by ISH and IHC methods in 20 cases of human breast carcinoma

\begin{tabular}{lcc}
\hline Tumour type & IHC & ISH \\
\hline Infiltrating ductal carcinoma & $8 / 15$ & $6 / 15$ \\
In situ ductal carcinoma & $3 / 4$ & $0 / 4$ \\
Invasive papillary carcinoma & $0 / 1$ & $0 / 1$ \\
Total & $11 / 20$ & $6 / 20$ \\
\hline
\end{tabular}



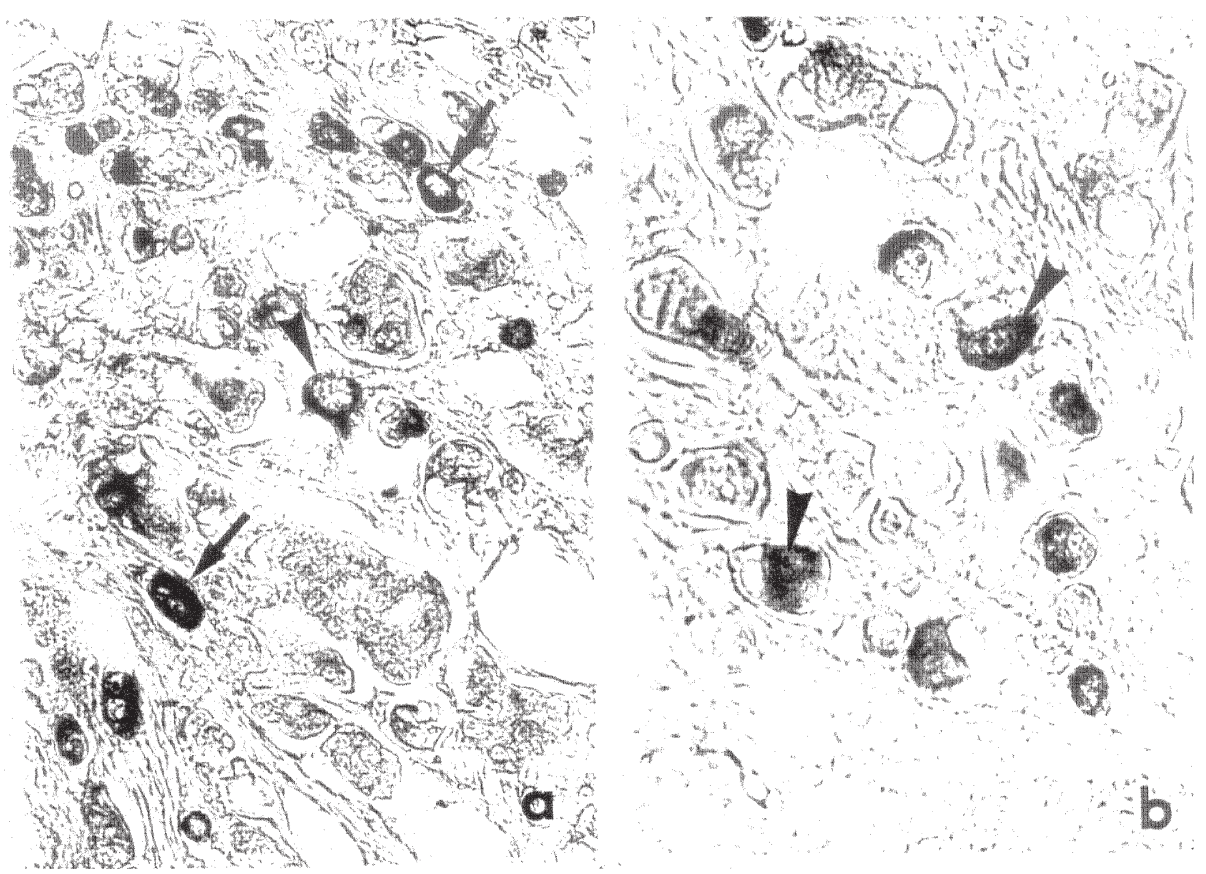

Fig. 1. c-erbB-2 mRNA hybridisation signals are seen in the tumour cell cytoplasm of infiltrating ductal carcinomas $((a) \times 200$, (b) $\times 400$ ). An intense (arrow) or moderate (arrow head) ISH signals are seen in some cells. Method: in situ hybridisation using DIG-labelled c-erbB-2 antisense oligoprobe (40-mer) on formalin-fixed paraffin-embedded breast tissue sections.
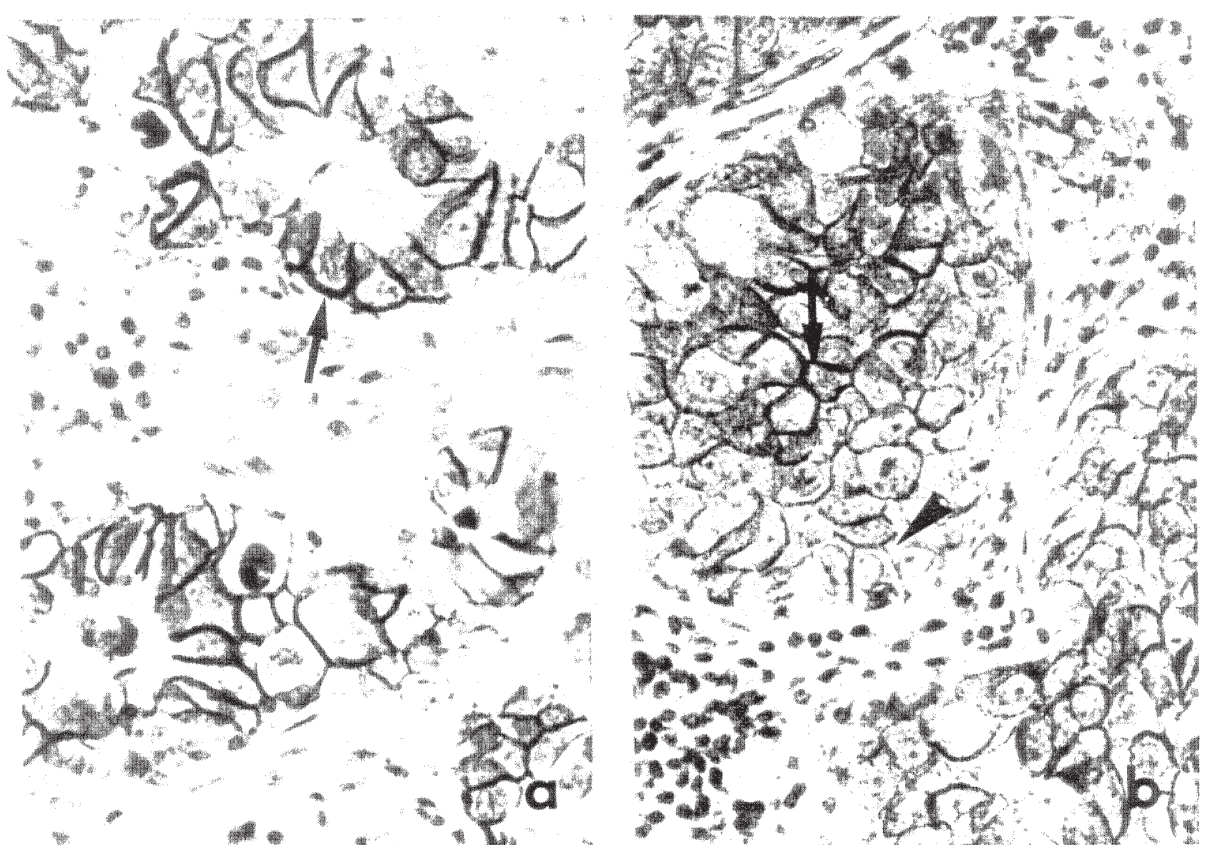

Fig. 2. Immunohistochemical staining for c-erbB-2 oncoprotein on formalin-fixed paraffin-embedded sections from primary breast carcinoma. Tumour cells with markedly (arrow) or weak (arrow head) stained membranes are seen in infiltrating ductal carcinomas (a), (b). Some of the tumour cells show faint cytoplasmic staining (b). Method: immunoperoxidase staining technique using monoclonal c-erbB-2 antibody. Counterstain hematoxylin. $\times 400$. 
Table 2

Correlation of c-erbB-2 overexpression of its mRNA by in situ hybridisation (ISH) and oncoprotein by immunohistochemistry (IHC) in various subtypes of breast carcinoma

\begin{tabular}{clccc}
\hline Case & Tumour type & Grade & ISH & IHC \\
\hline 1 & IDC + in situ DC & II & - & + \\
2 & IDC & II & - & - \\
3 & IDC & III & - & + \\
4 & IDC + in situ DC & II & - & + \\
5 & IDC & II & - & - \\
6 & IDC & III & + & + \\
7 & IDC & III & - & - \\
8 & IDC & II & - & + \\
9 & IDC & II & + & + \\
10 & IDC & II & + & + \\
11 & IDC + in situ DC & III & - & + \\
12 & IDC & II & + & + \\
13 & IDC & III & - & - \\
14 & IDC & II & - & + \\
15 & IDC & III & + & - \\
16 & IDC & III & - & - \\
17 & IPC & - & - & - \\
18 & IDC & II & - & - \\
19 & IDC & III & + & + \\
20 & IDC + in situ DC & II & - & - \\
\hline
\end{tabular}

IDC: infiltrating ductal carsinoma, IDC + in situ DC: infiltrating ductal carcinoma with extensive in situ component, IPC: invasive papillary carcinoma.

\section{Discussion}

A majority of the studies have shown that amplification and overexpression of c-erbB-2 is an indicator of poor prognosis in breast cancer. In recent years, a few comprehensive studies have been reported between gene amplification and overexpression of its m-RNA and protein, and shown that a high level of m-RNA expression could occur without gene amplification $[1,13]$. The regulatory mechanisms c-erbB-2 oncogene expression are poorly understood. Sarkar et al. [22] have isolated a transcription factor playing a role in the regulation of gene transcription, causing elevated expression of c-erbB-2 gene product independent of amplification. Karlan et al. [12], on the other hand, have reported that steroid hormones are effective in posttranscriptional mechanisms and glycocorticoids may control c-erbB-2 gene expression.

Detection of c-erbB-2 overexpression independent of gene amplification is important for the effective role in the pathogenesis of breast and other cancers. It has been used immunohistochemistry to determine oncoprotein $[2,21,25,27]$, or PCR $[8,26]$ and DNA hybridisation techniques $[4,11,26,17]$ to determine c-erbB-2 gene amplification, and these techniques have been suggested to rutin laboratories. But if overproduction of c-erbB-2 mRNA without amplification occurs, the DNA ISH method will be inefficient for the determination of it. However, with mRNA ISH method the assessment of mRNA overexpression with or without gene amplification will be possible. It has been shown by correlation of ISH and Northern blot analysis that ISH more sensitive for identifying small subclones of positive cells within a tumour sample than the blotting method [9]. 
The usage of DIG- [6,29], biotin- [20,30] or fluorescent-labelled [11,17] probes and administration of ISH to determine overexpression mRNA or gene amplification in various tissues and breast carcinomas have constituted an alternative against the usage of radioisotope-labelled probes. In the present study, non-isotopic, DIG-labelled, ISH protocol was used for the first time in determining c-erbB-2 mRNA transcripts in primary breast carcinomas. We optimised the ISH protocol to this tissue and to the laboratory conditions. In the proteinase digestion step of nonradioactive ISH administrations, pepsin or proteinase-K can be used according to the tissue types. In formalin-fixed paraffin-embedded tissue sections, tissue m-RNAs need to be accessed in the tissue section, and this can be conveniently carried out by limited proteinase treatment, which is believed to reduce the extent of crosslinking of intracellular protein, thus allowing the target nucleic acid to be detected by the relevant probe [7]. In the present study, as a result of our administrations of proteinase- $\mathrm{K}$, a high background was obtained. We both achieved optimum morphology and, at the same time, determined that background was hindered as a result of pepsin administrations. Mild acid pre-treatment is occasionally needed to prevent non-specific signals and improve the signal [19]. 0.2 M HCI administration specified in our protocol was established to be a step reducing background in the tissues. By the modification expressed above non-radioactive in situ hybridisation method allowed us to detect c-erbB-2 mRNA contents in the breast carcinoma easily and rapidly. DIG-labelled probes have several advantages over the other labels (e.g., radioactive or fluorescent). These probes are highly sensitive, stable for a long period and allow high levels of morphological resolution.

In this study, the tumour cells in 6 of 20 (30\%) primary breast carcinoma cases were positive for c-erbB-2 mRNAs. Five cases which has IHC positive for c-erbB-2 of 11/20 cases gave positive signals, whereas six were negative. According to these results, the oncoprotein overproduction occurs as related to the mRNA overexpression. However, only in one case, in spite of the mRNA signal being positive, the IHC signal was negative. In relation to the results of other similar studies [1,33], in the present study we also determined ISH positive and IHC negative signals. In the case of mRNA signal positivity and IHC signal negativity it might be due to c-erbB-2 mRNA is overexpressed, but the oncoprotein is not localised in the plasma membrane. Interestingly, this case had a cytoplasmic positive staining, but it was not evaluated as immunoreactive because it did not demonstrate a distinct membrane staining. Recently, Keshgegian et al. [13] suggested that c-erbB-2 oncoprotein cytoplasmic positivity was associated with a poor prognosis and seemed to have biological significance. The comparative studies with larger number of samples to determine the association or relationship of cytoplasmic immunoreactivity and mRNA and their distribution in tumour cells will provide additional information and clarity to these subject.

In IHC positive but ISH negative samples the negativity may be due to the mRNA loss during fixation procedures. However, in this tissue which has a positive signal with poly-d(t) control probes, the absence of c-erbB-2 mRNA signals can be explained with the assumption by Singleton et al. [27] that tumour cells have slightly overproduction of c-erbB-2 protein without increased levels of mRNA or DNA.

There was variation in mRNA staining intensity of the tumour cells within the same tissue section. It may be due to different mRNA level in these cells, whereas the variation of the hybridisation signal intensity between the different cases may be from the different mRNA levels and/or histological procedures. There was not a significant difference in the c-erbB-2 ISH signals and IHC reactivity between the newly prepared and archival tissue sections.

Overexpression or amplification of c-erbB-2 detects mainly aggressive lesions such as in situ carcinomas (comedo or non-comedo) [10,16,27] and infiltrating carcinomas [3,18]. It has been suggested that c-erbB-2 amplification was more common in advanced primary cancers than in early stage primary cancers, and speculated that an increase in numbers of a growth factor receptor might provide the invasive 
breast carcinoma cells with a proliferative advantage [34,35]. In our study, c-erbB-2 protein and mRNA overexpression were found in mainly primary infiltrating ductal carcinomas of grades II and III. This shows that c-erbB-2 expression contributes to the proliferative activity, progression and spread of breast cancer similar to previous studies [34,35].

By using mRNA ISH method for determination of the overexpression of gene for either amplification or regulation of transcription, we can also preserve histological morphology of the tissue. Therefore, we have applied non-radioactive ISH method to paraffin-embedded tumour samples to establish the most relevant condition to the tissue. The modifications reported above for the non-radioactive ISH method allowed us to detect mRNA contents in the breast tissue easily and rapidly. Similar to Szakacs et al.'s study [30], our results show that the mRNAs are highly preserved in routinely fixed material. We suggest this method as a relevant technique for the assessment of c-erbB-2 overexpression in routine laboratories both in newly processed material as well as in archival material.

\section{Acknowledgements}

We are grateful to Dr. D.J.S. Srinatsinghji and B. Havens for the labelling of the probes, and thanks to Dr. S. Türkoğlu and Dr. Sennur Ilvan for advice and contributions. This work was supported by the Research Fund of the University of Istambul (project number: YP/G-23).

\section{References}

[1] D. Bandyopadhyay, H.D. Dani, U.C. Samant, A.A. Redkar and I. Mittra, Correlations between cerbB2 oncogene amplification and the expression of its mRNA and protein in human breast carcinomas, Oncology 49 (1992), 9-14.

[2] H. Battifora, M. Gaffey, J. Esteban, P. Mehta, A. Bailey, C. Faucett and J. Niland, Immunohistochemical assay of neu/ cerbB2 oncogene product in paraffin-embedded tissues in early breast cancer: retrospective follow-up study of 245 stage I and II cases, Mod. Pathol. 4(4) (1991), 466-474.

[3] A.L. Borresen, L. Ottestad, A. Gaustad, T.I. Andersen, R. Heikkila, T. Jansen, K.M. Tweit and J.M. Nesland, Amplification and protein overexpression of the neu/her $2 /$ cerbB2 protooncogene in human breast carcinomas: relationship to loss of gene sequences on chromosome 17, family history and prognosis, Br. J. Cancer 62 (1990), 585-590.

[4] M.G. Clark and W.L. McGuire, Follow-up study of Her2/neu amplification in primary breast cancer, Cancer Res. 51 (1991), 944-948.

[5] L. Coussens, T.L. Yang-Feng, Y.C. Liao, E. Chen, A. Gary, J. McGrath, P.H. Seeburg, T.A. Libermann, J. Schlessinger and U. Francke, Thyrosin kinase receptor with extensive homology to EGF receptor shares chromosomal location with neu oncogene, Science 230 (1985), 1132-1139.

[6] H.B.P.M. Dijkman, S. Mentzel, A.S. DeJong and K.J.M. Assmann, RNA in situ hybridisation using digoxigenin-labelled cRNA probes, Biochimica 2 (1995), 21-25.

[7] P.C. Emson, In situ hybridisation as a methodological tool for the neuroscientist, TINS 16(1) (1993), 9-16.

[8] T.I. Gramlich, C. Cohen, C. Fritsch, P.B. DeRose and T. Gansler, Evaluation of cerbB2 amplification in breast carcinoma by differential polymerase chain reaction, Am. J. Clin. Pathol. 101(4) (1994), 493-499.

[9] R. Greil, B. Fasching and H. Huber, In situ hybridisation for detection of low copy numbers of c-abl oncogene mRNA in lymphoma cells: technical approach and comparison with results with anti-oncoprotein antibodies, Lab. Invest. 60 (1989), $572-582$.

[10] B.A. Gusterson, L.G. Machin, W.J. Gullick, N.M. Gibbs, T.J. Powles, P. Price and A. McKinna, Immunohistochemical distribution of cerbB2 in infiltrating and in situ breast cancer, Int. J. Cancer 42 (1988), 842-884.

[11] O.P. Kallioniemi, A. Kallioniemi, W. Karisu, A. Thor, L.C. Chen, H.S. Smith, F.M. Waldman, D. Pinkel and J.W. Gray, ERBB2 amplification in breast cancer analysed by fluorescence in situ hybridisation, Proc. Natl. Acad. Sci. USA 89 (1992), $5321-5325$

[12] B.Y. Karlan, J.L. Jones, D.J. Slamon and L.D. Lagasse, Glucocorticoids stabilise HER-2 tyrosine kinase pathway targets estrogen receptor and promotes hormone in human breast cancer cells, Oncogene 10 (1995), 2435-2446.

[13] A.A. Keshgegian and A. Cnaan, Erbb2 oncoprotein expression in breast carcinoma: poor prognosis associated with high degree of cytoplasmic positivity using CB-11 antibody, Am. J. Clin. Pathol. 108 (1997), 456-463. 
[14] C.R. King, S.M. Swain, L. Porter, S.M. Steinberg, M.E. Lippman and E.P. Gelmann, Heterogeneous expression of cerbB2 messenger RNA in human breast cancer, Cancer Res. 49 (1989), 4185-4191.

[15] U. Lönn, S. Lönn, U. Nylen, G. Winblad and B. Stenkvist, Amplification of oncogenes in mammary carcinoma shown by fine-needle biopsy, Cancer 67 (1991), 1396-1400.

[16] H.C. Maguire, M.E. Hellman, M.I. Greene and I. Yeh, Expression of cerbB2 in in situ and in adjacent invasive ductal adenocarcinomas of the female breast, Pathobiology 60(3) (1992), 117-121.

[17] G. Pauletti, W. Godolphin, M.F. Press and D.J. Slamon, Dedection and quantation of HER 2/neu gene amplification in human breast cancer archival material using fluorescence in situ hybridisation, Oncogene 13 (1996), 63-72.

[18] C. Pechoux, Y. Chardonnet and P. Noel, Immunohistochemical studies on cerbB2 oncoprotein expression in paraffinembedded tissues in invasive and non-invasive human breast lesions, Anticancer Res. 14 (1994), 1343-1350.

[19] H.W. Pringle, Non-isotopic detection of RNA in situ, in: Non-Isotopic Methods in Molecular Biology. A Practical Approach, E.R. Levy and C.S. Herrington, eds, Oxford University Press, Oxford, 1995, pp. 84-110.

[20] J.H. Pringle, A.K. Ruprar, L. Primrose, J. Keyte, L. Potter, P. Close and I. Lauder, In situ hybridisation of immunoglobulin light chain mRNA in paraffin sections using biotinylated or hapten-labelled oligonucleotide probes, J. Pathol. 162 (1990), 197-207.

[21] S. Ramachandra, L. Machin, S. Ashley, P. Monaghan and B.A. Gusterson, Immunohistochemical distribution of cerbB2 in situ breast carcinoma: a detailed morphological analysis, J. Pathol. 161(1) (1990), 7-14.

[22] F.H. Sarkar, M.R. Smith, T. Hoover, G. Pricler, J.D. Crissman, D.W. Visscher, D.L. Longo, H.F. Kung and Raziuddin, c-erbB-2 promoter-specific DNA binding protein isolated from human breast cancer tissues displays mitogenic activity, J. Biol. Chem. 269(16) (1994), 12 285-12 289.

[23] K. Sasaki, Y. Tomita, M. Azuma, S. Shida and B. Simizu, Amplification and overexpression of the cerbB2 protooncogene in human gastric cancer, Gastroenterol. Jpn. 27(2) (1992), 172-178.

[24] K. Sato, M. Moriyama, S. Mori, M. Saito, T. Watanuki, K. Terada, E. Okuhura, T. Akiyama and K. Totoshima, An immunohistologic evaluation of cerbB2 gene product in patients with urinary bladder carcinoma, Cancer 70(10) (1992), 2493-2498.

[25] H. Schimmelpenning, E.T. Eriksson, L. Pallis, L. Skoog, B. Cedermark and G.U. Auer, Immunohistochemical cerbB-2 protooncogene expression and nuclear DNA content in human mammary carcinoma in situ, Am. J. Clin. Pathol. 97 (1992), $48-52$.

[26] R. Sestini, C. Orlando, L. Zentilin, S. Gelmini, P. Pinzani, S. Bianchi, C. Selli, M. Giacca and M. Pazzagli, Measuring cerbB2 oncogene amplification in fresh and paraffin-embedded tumours by competitive polymerase chain reaction, Clin. Chem. 40(4) (1994), 630-636.

[27] T.P. Singleton, G.A. Nrehans, F. Gu, C.E. Litz, K. Hagen, Q. Qui, D.T. Kiang and J.G. Strickler, Detection of cerbB2 activation in paraffin-embedded tissue by immunohistochemistry, Hum. Pathol. 23 (1992), 1141-1150.

[28] D.J. Slamon, G.M. Clarck, S.G. Wong, W.J. Levin, A. Ullrich and W.L. McGuire, Human breast cancer; correlation of relapse and survival with amplification of the HER-2/neu oncogene, Science 235 (1987), 177-182.

[29] K.L. Smith, P.D. Robinson, H.J.S. Dawkins, J.M. Papadimitriou, S.L. Redmond, S. Carello, J.M. Harwey and G.F. Sterrett, cerbB2 amplification in breast cancer. Detection in formalin-fixed, paraffin-embedded tissue by in situ hybridisation, Hum. Pathol. 25 (1994), 413-418.

[30] J.G. Szakacs and S.K. Livingston, mRNA in situ hybridisation using biotinlated oligonucleotid probes: Implications for the diagnostic laboratory, Ann. Clin. Lab. Sci. 24(4) (1994), 324-338.

[31] F.A. Tavassoli, Pathology of the Breast, Appleton\&Lange, Norwalk, CT, 1992.

[32] M.J. Van de Vijver, J.L. Peterse, W.J. Mooi, P. Wisman, S.J. Loman, O. Dalesio and R. Nusse, Neu-protein overexpression in breast cancer. Association with comedo-type ductal carcinoma in situ and limited prognostic value stage II breast cancer, New Engl. J. Med. 319 (1988), 1239-1245.

[33] R.A. Walker, W.J. Gullick and J.M. Varley, An evaluation of immunoreactivity for cerbB-2 protein as a marker of poor short-therm prognosis in breast cancer, Br. J. Cancer 60 (1989), 426-429.

[34] T. Yamamoto, S. Ikawa, T. Akiyama, K. Semba, N. Nomura, N. Miyajima, T. Saito and K. Toyoshima, Similarity of protein encoded by the human cerbB2 gene to epidermal growth factor receptor, Nature 319 (1986), 230-234.

[35] D. Zhou, H. Battifora, J. Yokota, T. Yamamoto and M.J. Cline, Association of multiple copies of the cerbB2 oncogene with spread of breast cancer, Cancer Res. 47 (1987), 6123-6125. 


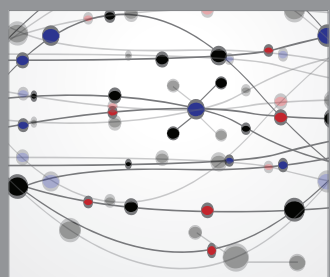

The Scientific World Journal
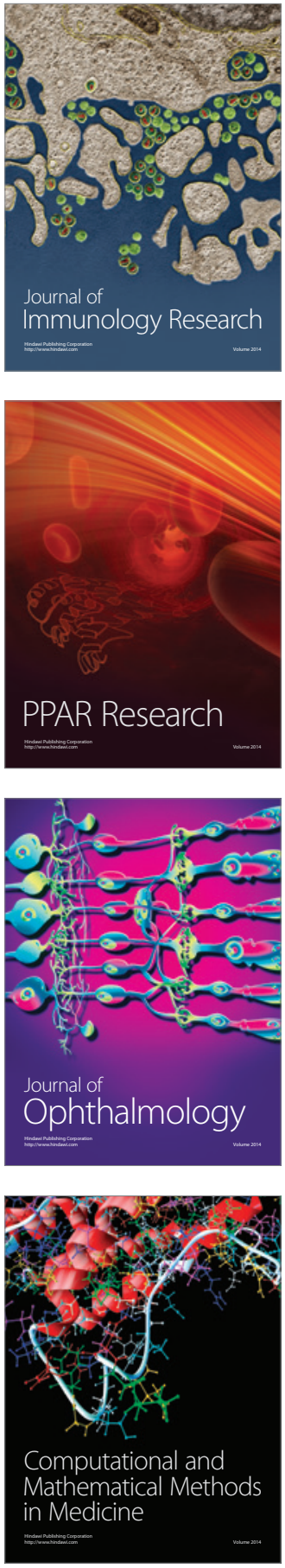

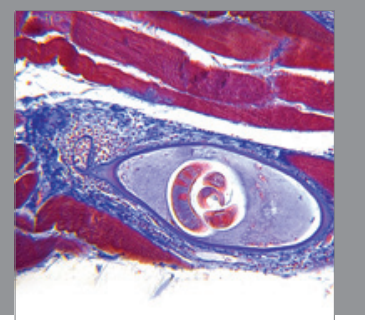

Gastroenterology

Research and Practice
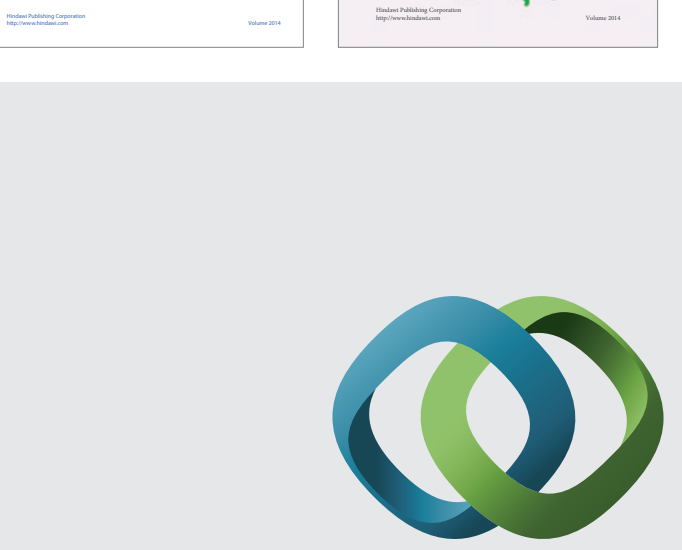

\section{Hindawi}

Submit your manuscripts at

http://www.hindawi.com
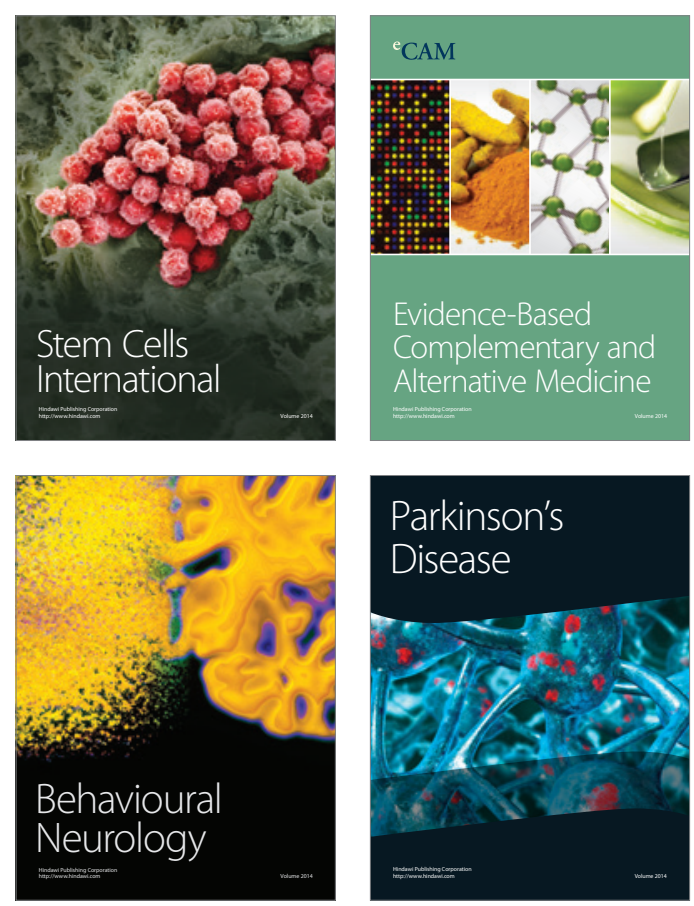

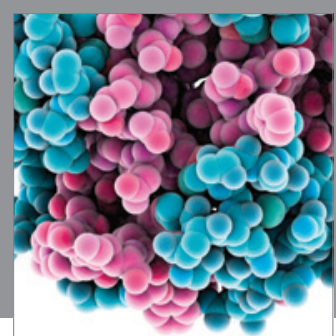

Journal of
Diabetes Research

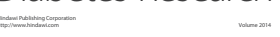

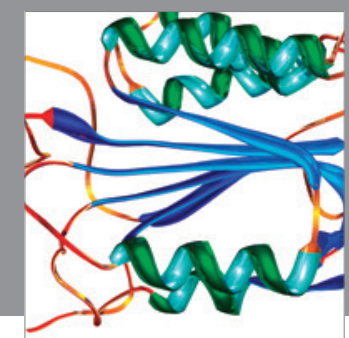

Disease Markers
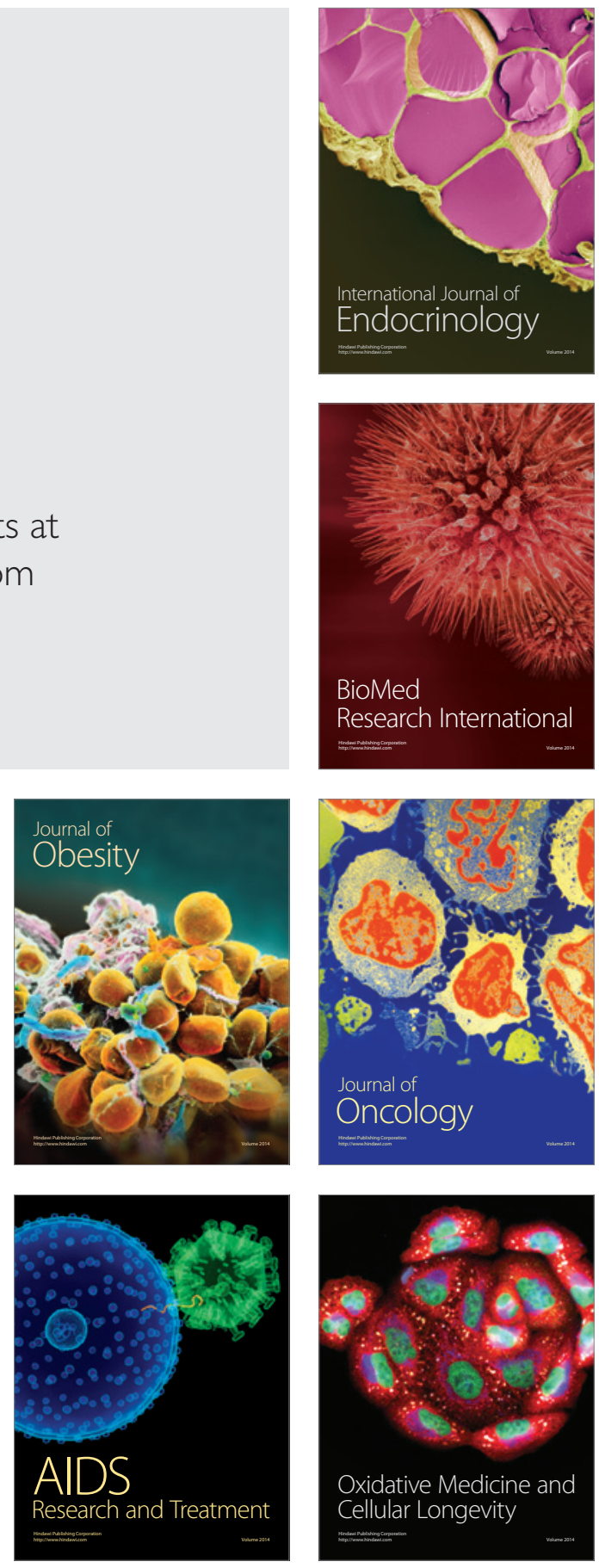